\title{
pro.posições
}

$e$-ISSN 1980-6248

http://dx.doi.org/10.1590/1980-6248-2018-0135EN

ARTIGOS

\section{Using project-based learning to teach project-based learning: lessons learned ${ }^{1,23}$}

\section{Usando aprendizagem baseada em projetos para ensinar aprendizagem baseada em projetos: as lições aprendidas}

João Alberto Arantes do Amaral (i)

(i) Universidade Federal de São Paulo - Unifesp, Osasco, SP, Brasil. https://orcid.org/0000-0001-

8312-740X, joaoalberto.arantes@gmail.com

\begin{abstract}
:
This article reports the lessons learned using a project-based learning (PBL) approach for teaching the project-based learning methodology itself. This study was conducted with 33 graduate students from the Faculty of Education of the University of São Paulo, Brazil. This paper explains the course goals, design, and curriculum. Data were collected by means of focus group activities, electronic surveys, and students' project websites, and analyzed to determine recurrent themes. The main findings were the following: (1) The course design, which followed the seven essential project design elements proposed by Larmer, Mergendoller, and Boss (2015), was very effective; (2) Centering learning around a meaningful project - the creation of a book about PBL experience - motivated students to do their best. However, the hard work came at a price: students reported experiencing fatigue and stress; and (3) The learning dynamics provided students with the experience of combining theory and practice, interviewing subjects, reflecting about the learning process, and sharing knowledge.

Keywords: teaching and learning, project-based learning, systemic impacts
\end{abstract}

\footnotetext{
${ }^{1}$ References correction and bibliographic normalization services: Lucas Giron (Tikinet) - revisao@tikinet.com.br

2 Copy editor: Janaina Almeida (Tikinet) - traducao@tikinet.com.br

${ }^{3}$ Responsible Editor: Silvio Donizetti de Oliveira Gallo. https://orcid.org/0000-0003-2221-5160
} 


\section{pro.posições}

http://dx.doi.org/10.1590/1980-6248-2018-0135EN

$e$-ISSN 1980-6248

\section{Resumo:}

Neste artigo, os autores apresentam as lições aprendidas usando a abordagem de aprendizagem baseada em projetos para ensinar a própria metodologia de aprendizagem baseada em projetos. Trinta e três alunos de pós-graduação da Faculdade de Educação da Universidade de São Paulo, Brasil, estiveram envolvidos. Este artigo explica os objetivos, a estruturação e o currículo do curso. Os dados foram coletados por meio grupos focais, questionários eletrônicos e website do projeto realizado pelos alunos. Os dados foram analisados para determinar temas recorrentes. As principais conclusões foram as seguintes: (1) A estruturação do curso, que seguiu os sete elementos essenciais de estruturação de um projeto, conforme proposto por Larmer, Mergendoller e Boss (2015), foi muito eficaz; (2) A centralização do aprendizado em torno de um projeto significativo - a criação de um livro sobre a experiências em aprendizagem baseada em projetos - motivou os alunos a fazer o melhor possivel para desenvolver o projeto. No entanto, o trabalho duro teve seu preço: os estudantes experimentaram fadiga e estresse; (3) A dinâmica da aprendizagem proporcionou aos alunos a experiência de combinar teoria com prática, entrevistar pessoas, refletir sobre o processo de aprendizagem e compartilhar conbecimentos.

Palavras-chave: ensino e aprendizagem, aprendizagem baseada em projetos, impactos sistêmicos

\section{Introduction}

This article presents the findings of a course using the Project-Based Learning (PBL) approach to teach PBL concepts to graduate students. Named "Project-based learning," the course was taught by the author himself to 33 students from the Faculty of Education of the University of São Paulo and lasted twelve weeks (from March to July 2018), with one threehour class per week.

The course aimed to teach the concepts of PBL through the development of a practical project: creating a book about the experiences of using Project-Based Learning in secondary schools and universities in Brazil. Working in teams of four (on average), the students developed nine projects in total, each resulting in the creation of a fifteen-page book chapter describing the experience of implementing PBL (courses and/or projects) in a different educational institution (Appendix 1). 


\section{pro.posıções}

$e$-ISSN 1980-6248

\section{Background: the project-based learning course}

The course was structured into four different development phases, each including one or more project deliverables (Figure 1); these were: preparation, planning, execution/control, and closure.

\begin{tabular}{|c|c|c|c|c|c|c|c|c|c|c|c|c|c|}
\hline & \multicolumn{12}{|c|}{ Weeks } \\
\hline & & 1 & 2 & 3 & 4 & 5 & 6 & 7 & 8 & 9 & 10 & 11 & 12 \\
\hline \multirow{4}{*}{$\begin{array}{l}\text { Project's } \\
\text { phases }\end{array}$} & Preparation & & & & & & & & & & & & \\
\hline & Planning & & 1 & & & & & & & & & & \\
\hline & Execution/Control & & & & & & & & & & & & \\
\hline & Closure & & & & & & & & & & & & \\
\hline
\end{tabular}

\begin{tabular}{|c|c|}
\hline Week & Projects' deliverables \\
\hline 1 & \\
\hline 2 & (1)Presentation of teams' structure and chosen project \\
\hline 3 & \\
\hline 4 & (2) Presentation of Projects planning \\
\hline 5 & 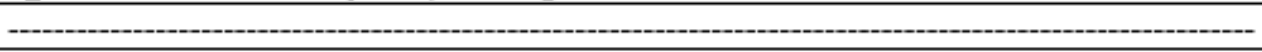 \\
\hline 6 & \\
\hline 7 & $\begin{array}{l}\text { (3) Presentation of the Projects status report, collected data, and book chapter } \\
\text { outline }\end{array}$ \\
\hline 8 & \\
\hline 9 & n-1, \\
\hline 10 & (4)Final presentation of the projects status report and created chapters \\
\hline 11 & (5) Final presentation of the projects status report and created chapters \\
\hline 12 & \\
\hline
\end{tabular}

Figure 1 - Project phases and deliverables

Source: The author

The preparation phase lasted two weeks. In the first week, the professor presented the course goals and provided students with a list of secondary schools and universities adherent to PBL. Then, students were asked to form teams and to choose the institution they wanted to research. For tracking project development, each team was instructed to create a website. In the second week, students presented their choices and the professor delivered a lecture on the basic concepts of PBL. 


\section{pro.posıções \\ $e$-ISSN 1980-6248}

http://dx.doi.org/10.1590/1980-6248-2018-0135EN

The planning phase occurred from weeks 2 to 6 , during which the students planned the research: who would be interviewed, when interviews would occur, what questions would be asked, and how the collected information would be analyzed. They also planned the writing of their chapters, dividing the tasks of drafting, revising, and making diagrams to accompany the text. During this phase, the professor taught students the basics of how to design and manage a PBL-centered educational project, introducing basic management tools such as the project charter, work breakdown structure (WBS), project evaluation and review technique (PERT), and critical path method (CPM). He also explained how to control project activities.

Project execution and control, the third phase of the course, began at week 3 and was developed until week 9. This phase comprised two project critique and revision meetings, the first of which occurred at week 4. In this meeting, students presented the team structure, the project schedule, and the plans developed, as well as their reflections on what they had learned until that moment. The second meeting occurred on week 7 , and students had to present the project status report, the data collected by means of interviews, and the outline of their book chapter. Besides receiving guidance from the professor and suggestions from their peers, these meetings enabled students to reflect on their own learning process and discuss the experience of learning PBL by actually engaging in a PBL-driven project. From weeks 7 to 9 , students developed project activities according to the professor's guidance and feedback from peers.

Finally, project closure phase began on week 10 and lasted until week 12. Students made their final presentations in weeks 10 and 11, discussing the chapter they had created and the lessons learned along the course. During these meetings, the professor conducted focus group activity with each team, collecting data on students' perceptions of the course. The professor also gave feedback on each project website, suggesting improvements and corrections. For collecting data on students' perceptions of the course design and their hands-on experience with PBL, the professor sent an electronic questionnaire to students at week 10. The course finished in week twelve, during which class the professor summarized the lessons he learned by analyzing data collected from focus group activities and questionnaires. 


\section{pro.posıções}

http://dx.doi.org/10.1590/1980-6248-2018-0135EN

$e$-ISSN 1980-6248

\section{Literature review}

Project-based learning (PBL) can be understood as an educational approach according to which students learn and develop skills by working in teams on meaningful real-world projects (Larmer \& Mergendoller, 2010). These projects may have different goals, such as creating products or services, solving a problem, or answering a question (Markham, 2003). In a typical PBL course, students are challenged to learn by getting their hands dirty (Hmelo-Silver, 2004), by discovering the necessary skills and materials to accomplish the project by themselves (Mills \& Treagust, 2003). They are also required to reflect on the learning process (Ayas \& Zeniuk, 2001) and present the project outcomes to an audience (Markham, 2011).

In a PBL-centered course, students follow a master schedule with clearly defined deliverables and milestones (Savery, 2015). Researchers indicate that PBL use can bring benefits such as improving students' motivation to learn (Bender, 2012) and fostering skills development (Jones et al., 1997).

Project-based learning has been used in all educational stages: primary (Kaldi et al., 2011), secondary (Hernández-Ramos \& De La Paz, 2009; Ravitz, 2010), and undergraduate education (de los Rios et al., 2010), as well as in graduate-level courses (Arantes do Amaral, 2018; Bielefeldt, 2013). Moreover, PBL has been used in different study fields, including the humanities (Jespersen, 2018), social sciences (Keiper, 1999), natural sciences (ChanLin, 2008; Holubova, 2008), formal sciences (Davenport, 2000), and applied sciences (Bielefeldt et al., 2013).

\section{How can teachers learn PBL methods?}

Teachers may learn PBL methods by self-study, for several books provide guidance on how to use the PBL method within the classroom (Bender, 2012; Boss \& Larmer, 2018; Grant, 2002). Institutions such as the Buck Institute for Education (BIE) and Edutopia also provide free on-line resources that include articles, project design rubrics, archived webinars, and PBL standards (Larmer et al., 2015). Moreover, different courses address educators at the undergraduate (Murray-Harvey et al., 2013) and graduate levels (Coelho, 2014; Hernandez et al., 2015). 


\section{pro.posıções \\ $e$-ISSN 1980-6248}

http://dx.doi.org/10.1590/1980-6248-2018-0135EN

However, before the scarcity of information about the use of PBL to teach PBL, our research addresses the following questions: 1) How can we design and implement a course on PBL following a PBL approach? 2) What dynamics would a course with these characteristics include?

\section{Method}

\section{The course design}

The course was designed to follow the seven essential project design elements proposed by Larmer et al. (2015), namely: the course should present (1) a challenging problem; the product created should be (2) authentic and (3) public; the course should stimulate (4) sustained inquiry, (5) reflection, and (6) critique and revision processes; and the students should have (7) voice and choice.

In the proposed project, the challenging problem was the creation of a book about PBL. The professor chose this problem because all students were teachers (from public and/or private schools and/or universities). Thus, he assumed that this challenge would be meaningful to them, for they had enrolled in the course with the purpose of learning more about this specific teaching and learning approach.

The course was designed to provide an authentic experience: students should have the opportunity to learn by engaging into a real-life project that would foster the development of their research and problem-solving skills, as well as their teamwork abilities and knowledge sharing. The course design included both field and classroom activities, so that in each class students would perform small group activities to become familiar with the tools that they would use to manage their projects.

The project deliverable was a book, whose own nature makes it a product accessible to a public audience. Moreover, the book was planned to be released two weeks after the end of the course, in a public ceremony to be held at the main auditorium of the Faculty of Education, in the presence of the authors' relatives and other scholars.

The course also sought to provide students with inquiry opportunities: they should both research PBL techniques and perform fieldwork activities, such as interviewing experts. 


\section{pro.posıções \\ e-ISSN 1980-6248}

http://dx.doi.org/10.1590/1980-6248-2018-0135EN

In addition to that, the course was planned to stimulate reflections on students' learning process by means of critique and revision meetings, during which students would have the opportunity to share what they had learned from their peers and to hear the professor's critiques and suggestions. Specific issues raised by the professor would allow the teams revise and improve their work.

The course also sought to provide students with voice and choice, allowing them to choose their team members, to define their roles and responsibilities, and to plan and conduct the interviews.

In short, the course design aimed to provide a total immersion in the PBL field: students would learn about PBL theory in the classroom and then apply this theory in a real-world project, which consisted of researching and writing about the use of PBL in different educational settings.

\section{Research design}

This is a qualitative research conducted with data collected by three different methods: focus group activities, an electronic survey applied to students, and students' projects websites. Data were analyzed by the language processing technique (Shiba et al., 1993), indicating the most recurrent themes. Finally, recurrent themes underwent a systemic analysis (Arantes do Amaral \& Gonçalves, 2015) by means of the construction of causal loop diagrams (Senge, 2014).

\section{Participants}

The research was conducted with the 33 students enrolled in the course. Participants consisted of 13 men and 20 women, aged from 22 to 49 years. Besides being graduate students, all were professors from public $(n=6)$ and private schools $(n=27)$.

As this was not a compulsory course, the students who chose to enroll had interest in learning about project-based learning methodology. 


\section{pro.posıções}

http://dx.doi.org/10.1590/1980-6248-2018-0135EN

$e$-ISSN 1980-6248

\section{Research instruments}

This research instruments were field notes (collected during focus group activities), the electronic survey (sent to students), and data collected from projects websites.

The focus groups were designed to understand team dynamics: their working issues, the research accomplished, the problem-solving processes, and group reflections on the learning process. As aforementioned, the focus group activities were performed at weeks 11 and 12, in which the professor acted as a moderator (Yin, 2015), encouraging each team to express their consensus and taking notes of their answers.

With the purpose of complementing the focus group, the professor designed a class survey with 7 open-ended questions (Appendix 1) aimed to verify how students felt about the project they had been working on and about the course itself. The survey was designed to provide data on individual perspectives rather than on team consensus (Sampieri et al., 2006), verifying students understanding of how the seven essential PBL design elements (Larmer et al., 2015) featured in their projects.

Finally, the professor also collected data from students' project websites, designed as project diaries (Arantes do Amaral et al., 2015) and thus providing useful information on team activities and the learning processes involved.

\section{Data analysis}

Data were analyzed following the method of qualitative analysis proposed by Shiba et al. (1993). First, sentences that dealt with similar issues were compiled into groups; then, correlated groups were clustered into broader categories and categorized by recurrent themes (RT) (Bradley et al., 2007). The associations between RT were identified by a systemic analysis (Arantes do Amaral \& Gonçalves, 2015; Wolstenholme \& Coyle, 1983). The main dynamics present in the course were verified by means of causal loop diagrams.

A causal loop diagram is a system dynamics modelling tool that represents a system feedback structures, showing variables, causal links, and feedback loops (Arantes do Amaral, 2019; Sterman, 2000). In a causal loop diagram, each two variables are interconnected by arrows with either positive or negative signs (causal links). Whereas a positive causal link is represented 


\section{pro.posições}

http://dx.doi.org/10.1590/1980-6248-2018-0135EN

$e$-ISSN 1980-6248

by an arrow with a positive sign, implying that both variables change in the same direction (Kirkwood,1998), a negative causal link is represented by an arrow with a negative sign, implying that the variables change in the opposite direction (Kirkwood,1998). Positive feedback loop (or reinforcing loop) represents a structure that leads to growth, while negative feedback loop represents a structure that leads to goal-seeking behavior. By analyzing the feedback loops interactions, one can understand the dynamics driving the system behavior (Senge, 2014).

\section{Reliability and validity}

According to Creswell and Creswell (2017), an investigation correctness (i.e. accurate and detailed phases that allow other researchers to follow the study methodology) assures the reliability of qualitative research. The author followed this recommendation, explaining each phase of the investigation in detail. A qualitative research validity can be assured by the proper interpretation of the data (Yin, 2015), which in this research was achieved by the combination of two methods: the language processing (Shiba, 1994; Shiba et al., 1993) and systemic analysis (Wolstenholme \& Coyle, 1983). Such method enabled the author to reveal the causal relationships among recurrent themes, thus assuring research validity.

\section{Findings}

\section{Findings from electronic survey}

Five recurrent themes emerged from the analysis of the students' answers:

RT1: The course stimulated research about PBL methodology and its different implementation forms.

The students reported that, to create the book chapter, they had to research both project-based learning methods and schools experience of implementing PBL.

One student wrote that:

We had to investigate deeply about PBL and we studied the theoretical reference made available by the professor. We also researched the schools experience with PBL, which would serve as a basis for writing our book chapter. This research involved reading school documents and interviewing students and teachers about their experience with PBL. 


\section{pro.posições \\ $e$-ISSN 1980-6248}

http://dx.doi.org/10.1590/1980-6248-2018-0135EN

RT2: The hands-on approach improved learning.

The students stressed that the need to accomplish the project tasks led them to develop skills such as communication, teamwork, and project management.

Regarding skills development, one student reported that:

I certainly developed communication skills, for I had to interact with the team members and to create the text to the book chapter.

Another student reflected on his experience of working in teams:

During the project, I made surprisingly discoveries: I learned that it is possible to work in teams in an organized way, to share the project responsibilities with my peers. I learned that it is essential to trust on the other team members.

One student stressed the importance of developing project management skills:

During the process, I learned how to create an efficient plan, how to follow the plan, and how to do interviews.

RT3: Classroom activities fostered reflection on the learning processes.

Students stated that, during the course, they had the opportunity to reflect on the PBL methodology and its characteristics.

Regarding classroom activities, one student stated that:

By learning PBL, by doing PBL, we were able to reflect on this methodology, to understand its challenges, and to verify that we can combine theoretical learning with skills development.

Another student commented that:

I learned the importance of giving students freedom to choose how to develop the project and to challenge them to develop critical thinking skills.

Another student indicated the importance of sharing knowledge and the professor's role as mediator of the reflection processes:

I learned in each phase of the project by debating with peers, by following what each team was creating, by the guidance given by the professor, and by analyzing the PBL practices of the institution that we were writing about.

RT4: Writing about PBL experiences motivated students.

Several students stated that writing a book about PBL experiences was a meaningful experience for them.

In this regard, one student commented that: 


\section{pro.posições}

http://dx.doi.org/10.1590/1980-6248-2018-0135EN

$e$-ISSN 1980-6248

Publishing a book was very inspiring: a book is a real product that presents real-life studies and is aimed to researchers that want to learn more about PBL practices.

RT5: The critique and revision processes fostered learning.

According to one student:

Critiques were always welcome: they helped us to identify flaws. The professor's critique also guided and oriented us.

Another student made an observation about the peer critiques:

On several occasions, I felt the need for asking my colleagues' opinions about the work I was doing, and I always got a feedback.

\section{Findings from the analysis of the teams' project websites}

One recurrent theme emerged from the analysis of the teams' project websites:

RT6: The students researched PBL methodology, academic writing, and project management.

Students wrote on their website that, besides researching PBL methodology, they also had to look into academic writing and project management during the project.

\section{Findings from focus group activities}

Two recurrent themes emerged from the focus group activities:

RT7: Answering the electronic surveys and updating the website fostered reflection about the learning processes.

Students stated that the weekly update of their website allowed them to reflect on their learning process.

RT8: The course was strenuous; it required a lot of work and rework.

Despite being rather meaningful and interesting, the students reported that the course was not easy to accomplish. According to them, they lacked training in research methodology, which hampered the process of writing a book chapter. Students also stated that the professor's demands for corrections led to an impressive amount of rework, and that meeting the weekly requirements of the course was extremely stressful. 


\section{pro.posıções}

http://dx.doi.org/10.1590/1980-6248-2018-0135EN

$e$-ISSN 1980-6248

\section{Discussion}

Figure 2 presents the causal loop diagram of the main dynamics throughout the course unfolding. The loop diagram indicates five positive feedback loops (namely "Leaning by researching," "Learning by doing," "Reflecting on learning," "Classroom activities foster students' engagement," and "Motivation makes the project advance") and one negative ("Stress and fatigue slow down the project"). This section explains each feedback loop and how they are connected.

RT4 (Writing about PBL experiences motivated students) shows that working on such a project was effective in driving motivation: the more the project advanced, the more motivated students became (Figure 2, "Motivation makes the project advance"). This finding corroborates those reported in other studies that have likewise found a correlation between purposeful activities and motivation (Wolk, 1994).

However, RT8 (The course was strenuous; it required a lot of work and rework) indicates that students experienced considerable stress in having to accomplish weekly tasks. The professor's demands for corrections also prompt the need for a series of rework, causing fatigue and thus negatively affecting the project progress ("Stress and fatigue slow down the project", Figure 2). These findings are aligned with those of studies on projects rework dynamics (Cooper, 1993; Cooper et al., 2002) and on the effects of fatigue and stress on learning (Ocak \& Uluyol, 2010).

Thus, the PBL course structure implied two opposite dynamics: "Motivation makes the project advance" (Figure 2), which contributed to the project development, and "Stress and fatigue slow down the project" (Figure 2), which pushed the project in the opposite direction.

RT1 (The course stimulate research about PBL methodology and its different implementation forms) and RT6 (The students researched academic writing and project management) indicate that the course stimulated researches throughout the project (Figure 2, "Learning by researching"). This finding corroborates those of studies addressing the importance of in-depth investigations in fostering students' learning (Grant, 2002). 


\section{pro.posıções \\ $e$-ISSN 1980-6248}

http://dx.doi.org/10.1590/1980-6248-2018-0135EN

Conversely, RT2 (The hands-on approach improved the learning) shows that, despite learning by researching, students also learned by doing (Figure 2, "Learning by doing") - in line with researchers who reported that hands-on experience helps students learning and developing skills (Bell, 2010).

RT5 (The critique and revision processes fostered learning) and RT7 (Answering the electronic surveys and updating the website fostered reflection about the learning processes) indicate that students also learned by reflecting upon their own learning (Figure 2, "Reflecting on the learning process"). This finding corroborates those reported by other researchers who discuss the importance of the critique and revision processes (Blumenfeld et al., 1991).

Finally, RT3 (Classroom activities fostered reflection on the learning processes) shows that activities developed within the classroom environment likewise contributed to the learning experience (Figure 2, “Classroom activities foster students' engagement"), which reiterates the findings reported by studies addressing the importance of reflection to the learning process (Boud et al., 2013). 


\section{pro.posições \\ $e$-ISSN 1980-6248}

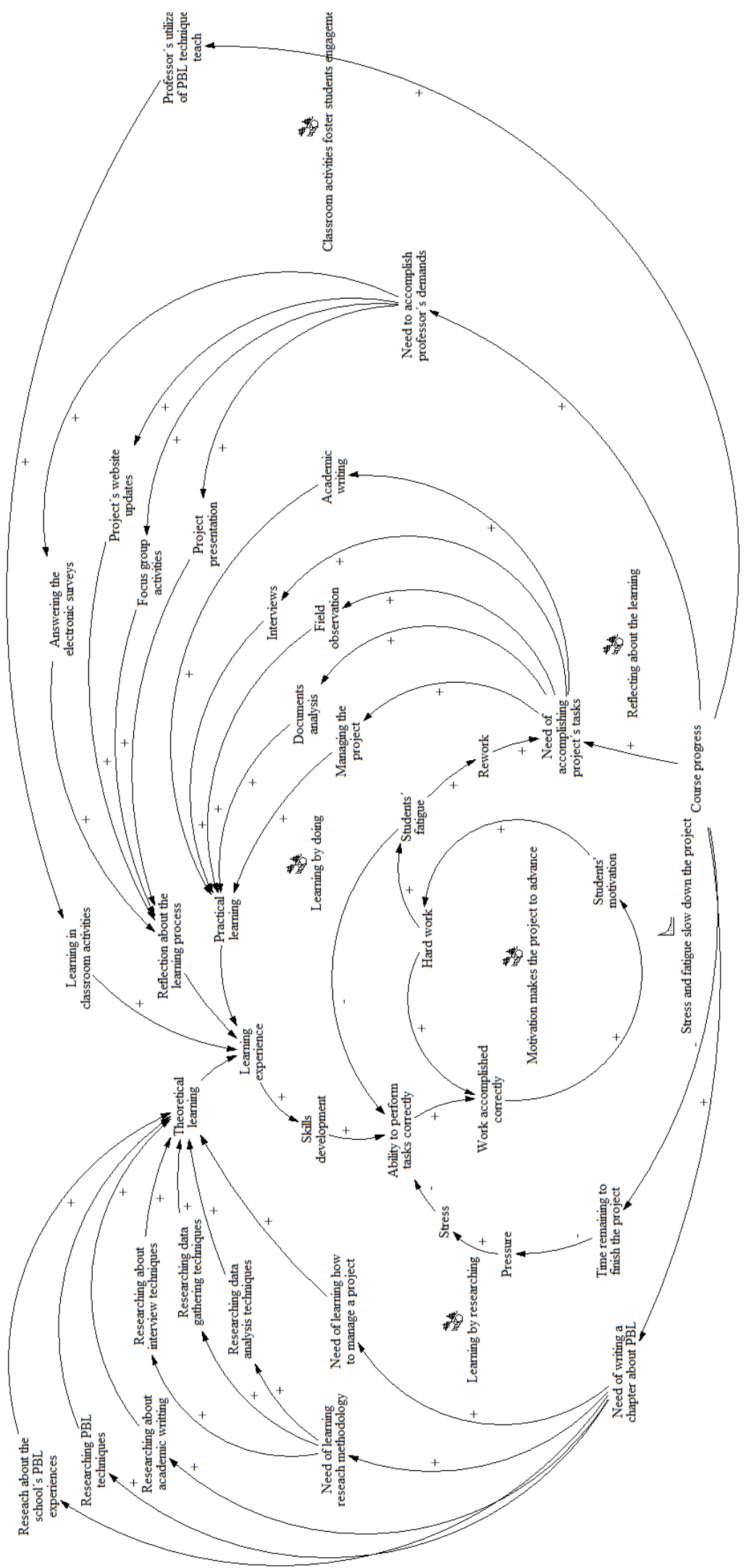

Figure 2-The course dynamics

Source: The author 


\section{pro.posıções \\ $e$-ISSN 1980-6248}

http://dx.doi.org/10.1590/1980-6248-2018-0135EN

\section{Conclusions}

So, what can we learn from this experience?

Addressing the first research question - "How to design and implement a course of PBL following a PBL approach?, - this study findings indicate that the seven essential project design elements (Larmer et al., 2015) were indeed very effective, for it allowed students to match the learned theory with the experienced practice. Students' voices highlighted that the project theme - that its, the creation of a book about PBL experience, - was a very good choice, motivating students to do their very best to develop the project. However, the hard work came at a price: students reported experiencing fatigue and stress.

As to our second question, "What dynamics would be present in a course with these characteristics?", the research indicates that the learning dynamics provided students with the experience of combining theory and practice, undertaking interviews, reflecting on the learning process, and sharing knowledge. We hope that the lessons learned from the analysis of this course may be useful to other scholars interested in designing similar educational experiences.

\section{Final remarks}

As planned, the book was released two weeks after the end of the course, in a public ceremony, and is now being used by scholars of the Faculty of Education of the University of São Paulo as a reference for graduate courses.

\section{References}

Arantes do Amaral, J. A. (2018). Reflections on thirteen years directing community-based learning projects. Collaborations: A Journal of Community-Based Research and Practice, 2(1), 2, $1-25$.

Arantes do Amaral, J. A. (2019). The cartoon guide to system dynamics.

Arantes do Amaral, J. A., \& Gonçalves, P. (2015). The use of system thinking concepts in order to assure continuous improvement of project based learning courses. Journal of Problem Based Learning in Higher Education, 3(2), 109-119. 


\section{pro-posıções \\ $e-$ ISSN 1980-6248}

http://dx.doi.org/10.1590/1980-6248-2018-0135EN

Arantes do Amaral, J. A., Gonçalves, P., \& Hess, A. (2015). Creating a project-based learning environment to improve project management skills of graduate students. Journal of Problem Based Learning in Higher Education, 3(2), 120-130.

Ayas, K., \& Zeniuk, N. (2001). Project-based learning: building communities of reflective practitioners. Management learning, 32(1), 61-76.

Bell, S. (2010). Project-based learning for the 21st century: skills for the future. The Clearing House, 83(2), 39-43.

Bender, W. N. (2012). Project-based learning: differentiating instruction for the 21 st century. Corwin.

Bielefeldt, A. R. (2013). Pedagogies to achieve sustainability learning outcomes in civil and environmental engineering students. Sustainability, 5(10), 4479-4501.

Blumenfeld, P. C., Soloway, E., Marx, R. W., Krajcik, J. S., Guzdial, M., \& Palincsar, A. (1991). Motivating project-based learning: Sustaining the doing, supporting the learning. Educational Psychologist, 26(3-4), 369-398.

Boss, S., \& Larmer, J. (2018). Project based teaching: how to create rigorous and engaging learning experiences. ASCD.

Boud, D., Keogh, R., \& Walker, D. (2013). Reflection: turning experience into learning. Routledge.

Bradley, E. H., Curry, L. A., \& Devers, K. J. (2007). Qualitative data analysis for health services research: developing taxonomy, themes, and theory. Health Services Research, 42(4), 17581772.

ChanLin, L.-J. (2008). Technology integration applied to project-based learning in science. Innovations in Education and Teaching International, 45(1), 55-65.

Coelho, C. (2014). Facilitating facilitators to facilitate, in problem or enquiry based learning sessions. Journal of Problem Based Learning in Higher Education, 2(1), 4-10.

Cooper, K. G. (1993). The rework cycle: how it really works... and reworks. PM Network, 2528.

Cooper, K. G., Lyneis, J. M., \& Bryant, B. J. (2002). Learning to learn, from past to future. International Journal of Project Management, 20(3), 213-219. 


\section{pro-posıções}

http://dx.doi.org/10.1590/1980-6248-2018-0135EN

$e-$ ISSN 1980-6248

Creswell, J. W., \& Creswell, J. D. (2017). Research design: qualitative, quantitative, and mixed methods approaches. Sage.

Davenport, D. (2000). Experience using a project-based approach in an introductory programming course. IEEE Transactions on Education, 43(4), 443-448.

de los Rios, I., Cazorla, A., Díaz-Puente, J. M., \& Yagüe, J. L. (2010). Project-based learning in engineering higher education: two decades of teaching competences in real environments. Procedia: Social and Behavioral Sciences, 2(2), 1368-1378.

Grant, M. M. (2002). Getting a grip on project-based learning: theory, cases and recommendations. Meridian: A Middle School Computer Technologies Journal, 5(1), 83-86.

Hernandez, C., Ravn, O., \& Valero, P. (2015). The Aalborg University PO-PBL Model from a Socio-cultural learning perspective. Journal of Problem Based Learning in Higher Education, $3(2), 16-36$.

Hernández-Ramos, P., \& De La Paz, S. (2009). Learning history in middle school by designing multimedia in a project-based learning experience. Journal of Research on Technology in Education, 42(2), 151-173.

Hmelo-Silver, C. E. (2004). Problem-based learning: what and how do students learn? Educational Psychology Review, 16(3), 235-266.

Holubova, R. (2008). Effective teaching methods: project-based learning in physics. US-China Education Review, 5(12), 27-36.

Jespersen, L. M. B. (2018). Problem orientation in art and technology. Journal of Problem Based Learning in Higher Education, 6(1), 1-14.

Jones, B. F., Rasmussen, C. M., \& Moffitt, M. C. (1997). Real-life problem solving: a collaborative approach to interdisciplinary learning. American Psychological Association.

Kaldi, S., Filippatou, D., \& Govaris, C. (2011). Project-based learning in primary schools: effects on pupils' learning and attitudes. Education 3-13, 39(1), 35-47.

Keiper, T. A. (1999). GIS for elementary students: an inquiry into a new approach to learning geography. Journal of Geography, 98(2), 47-59.

Kirkwood, C. W. (1998). System dynamics methods: a quick introduction. 


\section{pro.posições}

http://dx.doi.org/10.1590/1980-6248-2018-0135EN

\section{$e$-ISSN 1980-6248}

Larmer, J., \& Mergendoller, J. R. (2010). Essentials for project-based learning. Educational Leadership, 68(1), 34-37.

Larmer, J., Mergendoller, J., \& Boss, S. (2015). Setting the standard for project based learning. ASCD.

Markham, T. (2003). Project based learning handbook: a guide to standards-focused project based learning for middle and high school teachers. Buck Institute for Education.

Markham, T. (2011). Project based learning a bridge just far enough. Teacher Librarian, 39(2), 3842.

Mills, J. E., \& Treagust, D. F. (2003). Engineering education - is problem-based or projectbased learning the answer? Australasian Journal of Engineering Education, 3(2), 2-16.

Murray-Harvey, R., Pourshafie, T., \& Reyes, W. S. (2013). What Teacher Education Students Learn about Collaboration from Problem-Based Learning. Journal of Problem Based Learning in Higher Education, 1(1), 114-134.

Ocak, M. A., \& Uluyol, Ç. (2010). Investigation of students' intrinsic motivation in project based learning. Journal of Human Sciences, 7(1), 1152-1169.

Ravitz, J. (2010). Beyond changing culture in small high schools: reform models and changing instruction with project-based learning. Peabody Journal of Education, 85(3), 290-312.

Sampieri, R. H., Collado, C. H., Lucio, P. B., Murad, F. C., \& Garcia, A. G. Q. (2006). Metodologia de pesquisa. McGraw Hill.

Savery, J. R. (2015). Overview of problem-based learning: definitions and distinctions. In Walker A., Leary H., Hmelo-Silver C., \& Ertmer P. (Eds.), Essential readings in problem-based learning: exploring and extending the legacy of Howard S. Barrows (pp. 5-16). Purdue University Press.

Senge, P. M. (2014). The fifth discipline fieldbook: strategies and tools for building a learning organization. Crown.

Shiba, S. (1994). The language processing method. Center for Quality Management.

Shiba, S., Graham, A., \& Walden, D. (1993). A new American TQM: four practical revolutions in management. Productivity Press. 


\section{pro.posições \\ e-ISSN 1980-6248}

http://dx.doi.org/10.1590/1980-6248-2018-0135EN

Sterman, J. D. (2000). Business dynamics: systems thinking and modelling for a complex world. McGrawHill.

Wolk, S. (1994). Project-based learning: pursuits with a purpose. Educational Leadership, 52(3), $42-45$.

Wolstenholme, E. F., \& Coyle, R. G. (1983). The development of system dynamics as a methodology for system description and qualitative analysis. Journal of the Operational Research Society, 34(7), 569-581.

Yin, R. K. (2015). Qualitative research from start to finish. Guilford.

\section{Submission data:}

Submitted to evaluation on December 6, 2018; revised on July 29, 2019; accepted for publication on September 20, 2019.

Corresponding author: Universidade Federal de São Paulo - Unifesp, Departamento Multidisciplinar, R. Angélica, 100 - Jd. das Flores, Osasco - SP, São Paulo 04021-001. 


\section{pro.posıções}

$e$-ISSN 1980-6248

\section{Appendix 1. Book chapters}

\begin{tabular}{|c|c|}
\hline Institution & Book chapter name \\
\hline Oswald de Andrade School & Project-based learning in Oswald de Andrade School \\
\hline Santa Cruz School & $\begin{array}{l}\text { Project-based experience in secondary classes of Santa Cruz } \\
\text { School }\end{array}$ \\
\hline $\begin{array}{l}\text { Instituto Técnico Federal de } \\
\text { Capivari }\end{array}$ & $\begin{array}{l}\text { Project-based learning in a Chemistry course: the study of the } \\
\text { best teaching practices }\end{array}$ \\
\hline Evoluir Educational Center & Project-based learning as business: the Evoluir's experience \\
\hline Projeto Âncora School & Projeto Âncora School: a case study of learning communities \\
\hline Villare School & The project-based experience of School Villare \\
\hline British College of Brazil & The PBL experience of British College of Brazil \\
\hline Arapiraca College & The Ominira project: a PBL experience \\
\hline Novo Mundo School & The PBL experience of Novo Mundo School \\
\hline
\end{tabular}

\section{Appendix 2. Survey questions}

1. PBL courses often pose a problem (or a guiding question) to investigate/solve/answer. What was the problem or question that you investigated/resolved/answered?

2. In a PBL course, students are expected to do researches to solve the problem (or seek answers to the guiding question). What research have you done? What subjects? In what way?

3. In a PBL course, the project is expected to be authentic, genuine (i.e. students are expected to create something for the real world by following processes, performing tasks, and using real tools). Tell me about the processes you participated in and the tasks you performed.

4. In a PBL course, students are expected to have voice and choice, to control some aspects of the project, to define the tasks to be managed and their roles. Tell me about the aspects of the project you have controlled and the choices you have made. 


\section{pro.posıções}

http://dx.doi.org/10.1590/1980-6248-2018-0135EN

$e$-ISSN 1980-6248

5. In a PBL course, students are expected to reflect upon the learning process. Tell me about what you learned throughout the process, as well as how and why you learned it.

6. PBL courses are expected to entail review and critique processes. Tell me about how the criticisms and suggestions received (from the professor and colleagues) have impacted your learning process and the book chapter development.

7. The product developed in PBL course is expected to be interesting, useful to someone, and to motivate students to give their very best. Tell me whether the book was a design theme with these characteristics. 